\title{
SYNTHESIS OF HIGHLY SELECTIVE NANO-STRUCTURED FUNCTIONALIZED SBA-15 METFORMIN PAL- LADIUM COMPOSITE CATALYST IN PARTIAL HYDROGENATION OF ALKYNES
}

\author{
REZA KIA KOJOORI *,I \\ ${ }^{I}$ Department of chemistry, Faculty of Science, East Tehran Branch, Islamic Azad University, Tehran, Iran
}

\begin{abstract}
In this research, a heterogeneous Nano-Structured functionalized SBA-15 metformin palladium composite catalyst is reported for the selective hydrogenation of alkynes. In the first place, A series of the heterogeneous mesoporous SBA-15 metformin palladium catalyst were prepared and afterwards the condition and the ratio of used materials were optimized to give rise a suitable high performance catalyst. The final nano-structured catalyst was characterized by X-ray powder diffraction, BET surface area, FT-IR spectrophotometer, Scanning electron microscopy (SEM) and Transmission electron microscopy (TEM) and served in partial hydrogenation of different alkynes, with high selectivity and high yield. The liquid phase hydrogenation was conducted under mild condition of room temperature and atmospheric pressure. The reactions were monitored every half an hour by gas chromatography and all of them were completed during 4-6 hours. The products were characterized by ${ }^{1} \mathrm{H}-\mathrm{NMR},{ }^{13} \mathrm{C}-\mathrm{NMR}$, FT-IR, and Mass Spectrometry (MS) that strongly confirmed the (Z)-double bond configuration of produced alkenes. This prepared catalyst is competitive with the best palladium catalysts known for the selective liquid phase hydrogenation of alkynes and can be easily recovered and regenerated with keeping high activity and selectivity over multiple cycles with a simple regeneration procedure.
\end{abstract}

Keywords: partial hydrogenation; selective; mesoporous silica; nano composite; alkynes; alkenes.

\section{INTRODUCTION}

Highly selective heterogeneous catalysis is very crucial for extending of sustainable catalyst. Thus, the catalysts with new design to achieve highly product selectivity are strongly desirable ${ }^{1-2}$. These catalysts are preferred to apply because of being recyclable and feasible use of them on fixed bed reactors. Therefore, development of new heterogeneous catalytic system with unique feature of selectivity control in a certain reaction is a main plan of modern chemistry.

Partial hydrogenation of a carbon-carbon triple bonds to double bonds is a very important synthetic reaction with high utilization both in the laboratory and on the industrial scale for the synthesis of fine and specialty chemicals ${ }^{3-4}$ In recent years, application and designing of highly selective catalyst for partial hydrogenation of alkynes has attracted more attention by virtue of its importance in synthesis of intermediate products ${ }^{5-9}$

The Lindlar catalyst (the $\mathrm{Pd}$ on the $\mathrm{CaCO}_{3}$ poisoned with lead (II) acetate) was the first instance of highly selective supported metal catalyst for liquid phase partial hydrogenation of alkynes to alkenes by utilizing of a suitable surface modifier basic compound such as quinoline. The role of lead in this catalyst is a dopant to promote the selective hydrogenation of alkynes to cis-alkenes while quinoline is applied to slow the reaction rate of the subsequent hydrogenation of the desired cis-alkenes to alkanes, so that achieving a very high selectivity to cis-alkenes ${ }^{3}$. Because of the undesirable toxic lead compounds and the soluble additive, consequently, it is necessary to develop new alternative greener heterogeneous catalysts for this type of selective catalytic reaction.

The design of a new catalyst with suitable features can be accessed by perception the basic mechanisms that result to the selective partial reduction of alkynes to alkenes over palladium catalysts, however, those are not yet fully explored. Nevertheless, much development has been achieved recently, including finding the key roles of surface ${ }^{10-11}$, the amount and type of palladium hydride species ${ }^{12-13}$, as well as the effect of surface modifier or additional metal dopants ${ }^{14-16}$.

Selectivity either be controlled by thermodynamic or kinetic effects. Thermodynamic effects include changing the relative binding properties of the alkynes over alkenes whereas kinetic effects includes altering the relative rates of hydrogenation. The different experiments show that kinetic effects are less important than thermodynamic effects, as the rates of reduction of alkynes to alkenes and alkanes have nearly the same order of magnitude. Selectivity is indispensably governed by thermodynamic effects, i.e. the adsorption strength of different unsaturated C-C bond on the active sites of metal.

Selectivity can be largely influenced by applying surface modifiers that adsorb stronger alkenes than alkynes to the surface ${ }^{17}$. Modifiers are compounds containing $\mathrm{N}$ or $\mathrm{S}$ atoms for liquid phase hydrogenation of alkynes. Therefore, development of new catalytic systems with suitable activity and selectivity that are easily separable and recyclable, is the case that draws attention of many researchers ${ }^{18-22}$. These catalytic systems include mesoporous silica supported Pd nanoparticles ${ }^{23-25}$

In this work, functionalized SBA-15 metformin palladium composites are used to play three roles, the first is to promote the reacting of the incorporated Pd through the chelating metformin sites, furthermore, the improved dispersion capability of the nanoparticles and last but not least, introducing a separable, recyclable, and reusable catalyst which shows an immobilized catalyst on the surface to facilitate catalyst recovering. Contrary to cases where the organic base modifier requires removal2 ${ }^{26}$, in this research, the metformin modifier represents an important role in adjusting the selectivity of the catalyst.

The final catalyst was applied in the selective hydrogenation of different alkynes. The results approved that the heterogeneous catalytic reaction was highly selective for selective partial hydrogenation of alkynes to Z-alkenes (scheme 1).

$$
\mathrm{R} \underset{\overline{(1)}}{\stackrel{\overline{(1)}}{\prime}} \mathrm{R}^{\prime} \stackrel{\text { SBA-15/Metformin/Pd (II) nanocomposite catalyst }}{\text { r.t. , 4-6 h, Methanol }} \underset{\mathrm{H}}{\mathrm{R}_{(2)}} \mathrm{L}_{\mathrm{H}}^{\mathrm{R}^{\prime}}
$$

Scheme 1. Selective partial hydrogenation of alkynes to Z-alkenes

\section{EXPERIMENTAL}

\subsection{Chemical materials and characterization}

All chemicals were purchased from Merck except Pluronic123, metformin hydrochloride and palladium acetate which were obtained from Aldrich. Transmission electron microscopy (TEM) images were performed using a Philips CM300 operated at $100 \mathrm{kV}$ electron beam accelerating voltage. Scanning electron microscopy (SEM) measurements were obtained using a KYKY-EM3200. X-ray powder diffraction data of the synthesized catalysts were collected on a Philips XPERT diffractometer using nickel filtered Cu Karadiation k= 1.5406 Å. BET surface area analysis was carried out on a Micromeritics TriStar 3000 apparatus. Infrared spectra were prepared on a TENSOR 27 FT-IR spectrophotometer, Bruker Corporation. ${ }^{1} \mathrm{H}$ and ${ }^{13} \mathrm{C}-\mathrm{NMR}$ spectra were recorded on a Brucker Advance spectrophotometer $(250 \mathrm{MHz})$ in $\mathrm{CDCl}_{3}$. The mass spectra were recorded on a Finnigan-MAT-8430EI-MS spectrometer at $70 \mathrm{eV}$; in $\mathrm{m} / \mathrm{z}$ (rel. \%).

2.2. Preparation of functionalized SBA-15/metformin nanoparticles

The synthesis of mesoporous SBA-15 was performed according to a wellknown procedure ${ }^{27}$. A $100 \mathrm{ml}$ round-bottom flask were introduced successively $50 \mathrm{ml}$ of dried toluene, $1.00 \mathrm{gr}$ of SBA- 15 and $0.6 \mathrm{gr}(2.99 \mathrm{mmol})$ of 3 -chloropropyltrimethoxysilane. The mixture was refluxed for $24 \mathrm{~h}$ under an inert atmosphere of anhydrous $\mathrm{N}_{2}$, filtered and washed subsequently with toluene, dichloromethane and methanol, dried under reduced pressure at $80^{\circ} \mathrm{C}$ for $10 \mathrm{~h}$, and chloropropyl- functionalized SBA-15 product was obtained. 
In the same another flask, to a solution of $1.00 \mathrm{~g}(5.86 \mathrm{mmol})$ of metformin hydrochloride in $30 \mathrm{ml}$ acetonitrile, $0.25 \mathrm{gr}(6.12 \mathrm{mmol}) \mathrm{NaOH}$ was added. The solution was stirred for 1 hour. Then $1.00 \mathrm{gr}(6.03 \mathrm{mmol}) \mathrm{KI}$ and $1.00 \mathrm{gr}$ of as-prepared 3-chloropropyl functionalized SBA-15 were added to the mixture and kept under reflux for $1 \mathrm{~h}$, filtered and washed with distilled water and dried at $80{ }^{\circ} \mathrm{C}$ under reduced pressure to afford 0.9 gr of metformin- functionalized mesoporous SBA-15 nanoparticles. catalyst

.3. Preparation of functionalized SBA-15/ metformin/ palladium (II)

$0.5 \mathrm{gr}$ functionalized SBA-15 with sillylchloropropyl and metformin was poured in $100 \mathrm{ml}$ flask and then $10 \mathrm{ml}$ acetone added to it. The mixture was stirred and $110 \mathrm{mg} \mathrm{Pd}(\mathrm{OAc})_{2}(0.49 \mathrm{mmol})$ added to the corresponding mixture and this mixture allowed to stir $24 \mathrm{~h}$ in room temperature. After that, the mixture was filtered and rinsed by acetone and dried THF twice. Then the solid was dried at $80^{\circ} \mathrm{C}$ under reduced pressure oven for $3 \mathrm{~h}$. The resulted brownish catalyst was obtained and its structure characterized by FT-IR

2.4. Partial hydrogenation of alkyne to corresponding alkene by functionalized SBA-15/ metformin/ palladium catalyst

$100 \mathrm{mg}$ prepared catalyst mixed with $100 \mathrm{cc}$ methanol was poured into the flask and $20 \mathrm{mmol}$ alkyne was added to this mixture. Hydrogenation set is filled with $\mathrm{H}_{2}$ in atmospheric pressure and hydrogenating was continued for 5 h. Progress of reaction was followed each $0.5 \mathrm{~h}$ by gas chromatography. After the completion of reaction and disappearing of starting alkyne that took 4-6 $\mathrm{h}$, crude product was filtered. The filtrate was evaporated at low pressure by rotary evaporator. The products were characterized by ${ }^{1} \mathrm{H}-\mathrm{NMR},{ }^{13} \mathrm{C}-\mathrm{NMR}$, FT-IR, MS, that strongly approved the (Z)-double bond configuration of produced alkene. The results of all experimental data associated with analysis; IR, ${ }^{1} \mathrm{HNMR},{ }^{13} \mathrm{C}-\mathrm{NMR}$ and Mass Spectrum are presented in the following:

2a) phenyl ethylene, IR $(\mathrm{KBr}) \mathrm{cm}^{-1}: 1630(\mathrm{C}=\mathrm{C}), 908,991(\mathrm{OOP}=\mathrm{CH})$; ${ }^{1} \mathrm{H}-\mathrm{NMR}\left(\mathrm{CDCl}_{3}\right), \delta: 5.18(\mathrm{dd}, \mathrm{J}=10.2 \mathrm{~Hz}, 2.1 \mathrm{~Hz}, 1 \mathrm{H}), 5.61(\mathrm{dd}, \mathrm{J}=16.8 \mathrm{~Hz}$, $\mathrm{J}=2.1 \mathrm{~Hz}, 1 \mathrm{H}), 6.65(\mathrm{dd}, \mathrm{J}=16.8 \mathrm{~Hz}, \mathrm{~J}=10.2 \mathrm{~Hz}, 1 \mathrm{H}), 7.33(\mathrm{t}, \mathrm{J}=7.5 \mathrm{~Hz}, 1 \mathrm{H})$, $7.40(\mathrm{t}, \mathrm{J}=7.5 \mathrm{~Hz}, 2 \mathrm{H}), 7.60(\mathrm{~d}, \mathrm{~J}=7.5 \mathrm{~Hz}, 2 \mathrm{H}),{ }^{13} \mathrm{C}-\mathrm{NMR}\left(\mathrm{CDCl}_{3}\right): 137.9$, 136.1, 128.6, 128.5, 127.9, 114.3. MS m/z: $104\left(100, \mathrm{M}^{+}\right), 103$ (41), 78 (35), 51 (17), 50 (7), 39 (6).

2b) 2-propen-1-ol, IR ( $\mathrm{KBr}) \mathrm{cm}^{-1}: 3350(\mathrm{OH}), 3080(=\mathrm{CH}), 1645(\mathrm{C}=\mathrm{C})$, $920(\mathrm{OOP}=\mathrm{CH}) ;{ }^{1} \mathrm{H}-\mathrm{NMR}\left(\mathrm{CDCl}_{3}\right), \delta: 1.95(\mathrm{~s}, \mathrm{OH}), 4.15(\mathrm{~d}, \mathrm{~J}=6.2 \mathrm{~Hz}, 2 \mathrm{H})$, $5.10(\mathrm{dd}, \mathrm{J}=16.8 \mathrm{~Hz}, \mathrm{~J}=2.1 \mathrm{~Hz}, 1 \mathrm{H}), 5.40(\mathrm{dd}, \mathrm{J}=10.2 \mathrm{~Hz}, \mathrm{~J}=2.1 \mathrm{~Hz}, 1 \mathrm{H}), 6.10$ (ddt, J=16.8 Hz, J=10.2 Hz, J=6.2 Hz, 1H), ${ }^{13} \mathrm{C}-\mathrm{NMR}\left(\mathrm{CDCl}_{3}\right): 60.2,115.7$, 138.2. MS m/z: $58\left(23, \mathrm{M}^{+}\right), 57$ (100), 39 (28), 31 (41), 29 (25), 27 (23).

2c) (Z)-2-buten-1-ol, IR (KBr) cm $\mathrm{cm}^{-1}: 3350(\mathrm{OH}), 3082(=\mathrm{CH}), 1658$ $(\mathrm{C}=\mathrm{C}), 670(\mathrm{OOP}=\mathrm{CH}) ;{ }^{1} \mathrm{H}-\mathrm{NMR}\left(\mathrm{CDCl}_{3}\right), \delta: 2.05(\mathrm{~d}, \mathrm{~J}=6.4 \mathrm{~Hz}, 3 \mathrm{H}), 3.65$ $(\mathrm{s}, \mathrm{OH}), 4.18(\mathrm{~d}, \mathrm{~J}=6.2 \mathrm{~Hz}, 2 \mathrm{H}), 5.64(\mathrm{td}, \mathrm{J}=10.9 \mathrm{~Hz}, \mathrm{~J}=6.2 \mathrm{~Hz}, 1 \mathrm{H}), 5.70$ (qd, $\mathrm{J}=10.9 \mathrm{~Hz}, \mathrm{~J}=6.4 \mathrm{~Hz}, 1 \mathrm{H}),{ }^{13} \mathrm{C}-\mathrm{NMR}\left(\mathrm{CDCl}_{3}\right) 11.6,57.9,125.9,130.6$. MS m/z: $72\left(33, \mathrm{M}^{+}\right), 57(100), 43$ (23), 41 (24), 39 (29), 31 (21), 29 (29), 27 (25).

2d) 3-buten-1-ol, IR (KBr) cm $\mathrm{cm}^{-1}: 3360(\mathrm{OH}), 3080(=\mathrm{CH}), 1641(\mathrm{C}=\mathrm{C})$, 990, $915(\mathrm{OOP}=\mathrm{CH}) ;{ }^{1} \mathrm{H}-\mathrm{NMR}\left(\mathrm{CDCl}_{3}\right), \delta: 2.32(\mathrm{td}, \mathrm{J}=7.1 \mathrm{~Hz}, \mathrm{~J}=6.2 \mathrm{~Hz}, 2 \mathrm{H})$, $2.76(\mathrm{~s}, \mathrm{OH}), 3.65$ (t, J=7.1 Hz, 2H), 5.10 (dd, $\mathrm{J}=10.0 \mathrm{~Hz}, \mathrm{~J}=2.1 \mathrm{~Hz}, 1 \mathrm{H}), 5.13$ (dd, J=16.8 Hz, J=2.1 Hz, 1H), 5.81 (ddt, J=16.8 Hz, J=10 Hz, J=6.2, 1H), ${ }^{13} \mathrm{C}-$ NMR ( $\left.\mathrm{CDCl}_{3}\right)$ 37.1, 61.6, 117.2, 135.0. MS m/z: 72 (7, $\left.\mathrm{M}^{+}\right), 42$ (100), 31 (67).

2e) 3-buten-2-ol, IR (KBr) cm $\mathrm{cm}^{-1}: 3390(\mathrm{OH}), 3080(=\mathrm{CH}), 1650(\mathrm{C}=\mathrm{C})$, 980, $922(\mathrm{OOP}=\mathrm{CH}) ;{ }^{1} \mathrm{H}-\mathrm{NMR}\left(\mathrm{CDCl}_{3}\right), \delta: 1.27(\mathrm{~d}, \mathrm{~J}=6.8 \mathrm{~Hz}, 3 \mathrm{H}), 2.06(\mathrm{~s}$, $\mathrm{OH}), 4.29(\mathrm{qd}, \mathrm{J}=6.8 \mathrm{~Hz}, \mathrm{~J}=6.2 \mathrm{~Hz}, 1 \mathrm{H}), 5.07(\mathrm{dd}, \mathrm{J}=10 \mathrm{~Hz}, \mathrm{~J}=2.1 \mathrm{~Hz}, 1 \mathrm{H})$, $5.21(\mathrm{dd}, \mathrm{J}=16.8 \mathrm{~Hz}, \mathrm{~J}=2.1,1 \mathrm{H}), 5.90(\mathrm{ddd}, \mathrm{J}=16.8 \mathrm{~Hz}, \mathrm{~J}=10 \mathrm{~Hz}, \mathrm{~J}=6.2 \mathrm{~Hz}$, $1 \mathrm{H}),{ }^{13} \mathrm{C}-\mathrm{NMR}\left(\mathrm{CDCl}_{3}\right) 23.0,68.8,113.6,142.6 . \mathrm{MS} \mathrm{m} / \mathrm{z}: 72\left(3, \mathrm{M}^{+}\right), 71(14)$, 57 (100), 43 (73), 29 (24), 28 (4).

2f) (Z)-2-buten-1,4-diol, IR (KBr) cm $\mathrm{cm}^{-1}: 3337(\mathrm{OH}), 3025(=\mathrm{CH}), 1660$ $(\mathrm{C}=\mathrm{C}), 690(\mathrm{OOP}=\mathrm{CH}) ;{ }^{1} \mathrm{H}-\mathrm{NMR}\left(\mathrm{CDCl}_{3}\right), \delta: 2.90(\mathrm{~s}, 2 \mathrm{OH}), 4.30(\mathrm{~d}, \mathrm{~J}=6.2$ $\mathrm{Hz}, 4 \mathrm{H}), 5.70(\mathrm{t}, \mathrm{J}=6.2 \mathrm{~Hz}, 2 \mathrm{H}),{ }^{13} \mathrm{C}-\mathrm{NMR}\left(\mathrm{CDCl}_{3}\right) 44.0,130.0 . \mathrm{MS} \mathrm{m} / \mathrm{z}: 70$ (38), 57 (100). 42 (95) 31 (55).

$2 \mathrm{~g})$ propenoic acid, IR $(\mathrm{KBr}) \mathrm{cm}^{-1}: 2400-3400(\mathrm{COOH}), 3070(=\mathrm{CH})$, $1705(\mathrm{C}=\mathrm{O}), 1636(\mathrm{C}=\mathrm{C}), 1245,1297(\mathrm{C}-\mathrm{O}), 987(\mathrm{OOP}=\mathrm{CH}) ;{ }^{1} \mathrm{H}-\mathrm{NMR}$ $\left(\mathrm{CDCl}_{3}\right), \delta: 5.75(\mathrm{dd}, \mathrm{J}=16.8 \mathrm{~Hz}, \mathrm{~J}=2.1 \mathrm{~Hz}, 1 \mathrm{H}), 6.22(\mathrm{dd}, \mathrm{J}=16.8 \mathrm{~Hz}, \mathrm{~J}=10.2$ $\mathrm{Hz}, 1 \mathrm{H}), 6.50(\mathrm{dd}, \mathrm{J}=10.2 \mathrm{~Hz}, \mathrm{~J}=2.1 \mathrm{~Hz}, 1 \mathrm{H}), 11.50\left(\mathrm{~s}, \mathrm{CO}_{2} \mathrm{H}\right),{ }^{13} \mathrm{C}-\mathrm{NMR}$ $\left(\mathrm{CDCl}_{3}\right): 127.5,134.1,170.4$. MS m/z: $72\left(95, \mathrm{M}^{+}\right), 55$ (97), 45 (32), 27 (100).

2h) (Z)-ethylen-dicarboxylic acid, IR $(\mathrm{KBr}) \mathrm{cm}^{-1}: 2400-3400(\mathrm{COOH})$, $3070(=\mathrm{CH}), 1705(\mathrm{C}=\mathrm{O}), 1635(\mathrm{C}=\mathrm{C}), 1220,1265(\mathrm{C}-\mathrm{O}), 950(\mathrm{OOP}=\mathrm{CH})$; ${ }^{1} \mathrm{H}-\mathrm{NMR}\left(\mathrm{CDCl}_{3}\right), \delta: 6.28(\mathrm{~s}, 2 \mathrm{H}), 11.03\left(\mathrm{~s}, 2 \mathrm{CO}_{2} \mathrm{H}\right),{ }^{13} \mathrm{C}-\mathrm{NMR}\left(\mathrm{CDCl}_{3}\right)$ 130.0, 166.5. MS m/z: $116\left(2, \mathrm{M}^{+}\right), 99(30), 72(100), 45$ (67), 26 (45).

2i) (Z)-1,2-diphenylethylene, IR $(\mathrm{KBr}) \mathrm{cm}^{-1}: 1600(\mathrm{C}=\mathrm{C}), 700$ (OOP $=\mathrm{CH}),{ }^{1} \mathrm{H}-\mathrm{NMR}\left(\mathrm{CDCl}_{3}\right), \delta: 6.56(\mathrm{~s}, 2 \mathrm{H}), 7.30(\mathrm{t}, \mathrm{J}=7.5 \mathrm{~Hz}, 2 \mathrm{H}), 7.45(\mathrm{t}, \mathrm{J}=$ $7.5 \mathrm{~Hz}, 4 \mathrm{H}), 7.72(\mathrm{~d}, \mathrm{~J}=7.5 \mathrm{~Hz}, 4 \mathrm{H}),{ }^{13} \mathrm{C}-\mathrm{NMR}\left(\mathrm{CDCl}_{3}\right): 127.4,127.9,128.5$, 128.6, 137.5. MS m/z: $180\left(100, \mathrm{M}^{+}\right), 179$ (92), 178 (50), 165 (38), 89 (12), $77(7)$. 2j) 1-pentene, IR $(\mathrm{KBr}) \mathrm{cm}^{-1}: 3080(=\mathrm{CH}), 1645(\mathrm{C}=\mathrm{C}), 910,990$ (OOP $=\mathrm{CH}),{ }^{1} \mathrm{H}-\mathrm{NMR}\left(\mathrm{CDCl}_{3}\right), \delta: 0.91(\mathrm{t}, \mathrm{J}=8 \mathrm{~Hz}, 3 \mathrm{H}), 1.43(\mathrm{qt}, \mathrm{J}=8 \mathrm{~Hz}, \mathrm{~J}=7.1 \mathrm{~Hz}$, 2H), $2.02(\mathrm{td}, \mathrm{J}=7.1 \mathrm{~Hz}, \mathrm{~J}=6.2 \mathrm{~Hz}, 2 \mathrm{H}), 4.93(\mathrm{dd}, \mathrm{J}=10.2 \mathrm{~Hz}, \mathrm{~J}=2.1 \mathrm{~Hz}, 1 \mathrm{H})$, $4.97(\mathrm{dd}, \mathrm{J}=16.8 \mathrm{~Hz}, \mathrm{~J}=2.1 \mathrm{~Hz}, 1 \mathrm{H}), 5.81(\mathrm{tdd}, \mathrm{J}=16.8 \mathrm{~Hz}, \mathrm{~J}=10.2 \mathrm{~Hz}, \mathrm{~J}=6.2 \mathrm{~Hz}$, $1 \mathrm{H}),{ }^{13} \mathrm{C}-\mathrm{NMR}\left(\mathrm{CDCl}_{3}\right)$ 13.7, 22.3, 36.1, 114.4, 139.0. MS m/z: $70\left(39, \mathrm{M}^{+}\right), 55$ (65), 42 (100), 29 (21), 27 (18).

2k) (Z)-2-pentene, IR (KBr) cm $\mathrm{cm}^{-1}: 3015(=\mathrm{CH}), 1667(\mathrm{C}=\mathrm{C}), 700$ (OOP $=\mathrm{CH}),{ }^{1} \mathrm{H}-\mathrm{NMR}\left(\mathrm{CDCl}_{3}\right), \delta: 0.96(\mathrm{t}, \mathrm{J}=8.0 \mathrm{~Hz}, 3 \mathrm{H}), 1.60(\mathrm{~d}, \mathrm{~J}=6.2 \mathrm{~Hz}, 3 \mathrm{H})$, $2.04(\mathrm{qd}, \mathrm{J}=8.0 \mathrm{~Hz}, \mathrm{~J}=6.2 \mathrm{~Hz}, 2 \mathrm{H}), 5.15(\mathrm{td}, 11.2 \mathrm{~Hz}, 6.2 \mathrm{~Hz}, 1 \mathrm{H}), 5.64(\mathrm{dq}, \mathrm{J}=$ $11.2 \mathrm{~Hz}, \mathrm{~J}=6.2 \mathrm{~Hz}, 1 \mathrm{H}),{ }^{13} \mathrm{C}-\mathrm{NMR}\left(\mathrm{CDCl}_{3}\right): 12.6,14.2,20.2,123.1,132.6$. MS $\mathrm{m} / \mathrm{z}: 70\left(39, \mathrm{M}^{+}\right), 55(100), 42$ (42), 29 (20).

21) 1-hexene, IR $(\mathrm{KBr}) \mathrm{cm}^{-1}: 3080(=\mathrm{CH}), 1642(\mathrm{C}=\mathrm{C}), 912(\mathrm{OOP}=\mathrm{CH})$, ${ }^{1} \mathrm{H}-\mathrm{NMR}\left(\mathrm{CDCl}_{3}\right), \delta: 0.90(\mathrm{t}, \mathrm{J}=8.0 \mathrm{~Hz}, 3 \mathrm{H}), 1.07(\mathrm{~m}, 2 \mathrm{H}), 1.50(\mathrm{~m}, 2 \mathrm{H}), 2.06$ $(\mathrm{td}, \mathrm{J}=7.1 \mathrm{~Hz}, 6.2 \mathrm{~Hz}, 2 \mathrm{H}), 4.92(\mathrm{dd}, \mathrm{J}=10.0 \mathrm{~Hz}, \mathrm{~J}=2.1 \mathrm{~Hz}, 1 \mathrm{H}), 4.96(\mathrm{dd}, \mathrm{J}=$ $16.8, \mathrm{~J}=2.1 \mathrm{~Hz}, 1 \mathrm{H}), 5.80$ (ddt, $\mathrm{J}=16.8 \mathrm{~Hz}, \mathrm{~J}=10.0 \mathrm{~Hz}, \mathrm{~J}=6.2 \mathrm{~Hz}, 1 \mathrm{H}),{ }^{13} \mathrm{C}-$ NMR $\left(\mathrm{CDCl}_{3}\right): 14.0,22.4,31.3,33.7,114.2,139.2$. MS m/z: $84\left(29, \mathrm{M}^{+}\right), 69$ (24), 56 (100), 42 (72), 41 (95), 29 (19).

$2 \mathrm{~m})$ 1-octene, IR $(\mathrm{KBr}) \mathrm{cm}^{-1}: 3075(=\mathrm{CH}), 1644(\mathrm{C}=\mathrm{C}), 991(\mathrm{OOP}=\mathrm{CH})$, ${ }^{1} \mathrm{H}-\mathrm{NMR}\left(\mathrm{CDCl}_{3}\right), \delta: 0.87(\mathrm{t}, \mathrm{J}=8.0 \mathrm{~Hz}, 3 \mathrm{H}), 1.04-1.53(\mathrm{~m}, 8 \mathrm{H}), 2.02(\mathrm{dt}, \mathrm{J}=7.2$ $\mathrm{Hz}, \mathrm{J}=6.2 \mathrm{~Hz}, 2 \mathrm{H}), 4.91(\mathrm{dd}, \mathrm{J}=10.2 \mathrm{~Hz}, \mathrm{~J}=2.1,1 \mathrm{H}), 4.97$ (dd, J=16.8 Hz, 2.1 $\mathrm{Hz}, 1 \mathrm{H}), 5.77$ (ddt, J=16.8 Hz, J=10.2 Hz, J=6.2 Hz, $1 \mathrm{H}),{ }^{13} \mathrm{C}-\mathrm{NMR}\left(\mathrm{CDCl}_{3}\right)$ : 14.1, 22.7, 28.9, 29.1, 31.9, 33.9, 114.1, 139.2. MS m/z: $112\left(20, \mathrm{M}^{+}\right), 83$ (34), 70 (86), 54 (99), 43 (100), 29 (35).

2.5. Catalyst recovering and regeneration

After completion of the reaction, the catalyst was filtered, rinsed with sufficient methanol and dried under vacuum at room temperature. Then the resulted powder was transferred into a flask and the system was purged with pure nitrogen for 15 minutes.

\section{RESULTS AND DISCUSSION}

3.1. Synthesis and characterization of functionalized SBA-15/Metfor$\min / \mathbf{P d}$ (II)

The schematic pathways for the synthesis of catalyst are depicted in Scheme $2 \mathrm{a}$ and $2 \mathrm{~b}$.

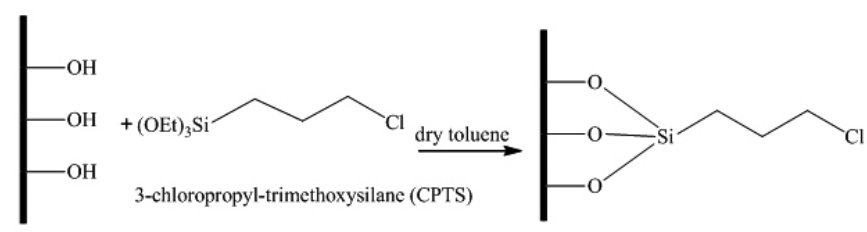

Mesoporous silica (SBA-15)

Sillylchloropropyl-functionalized SBA-15
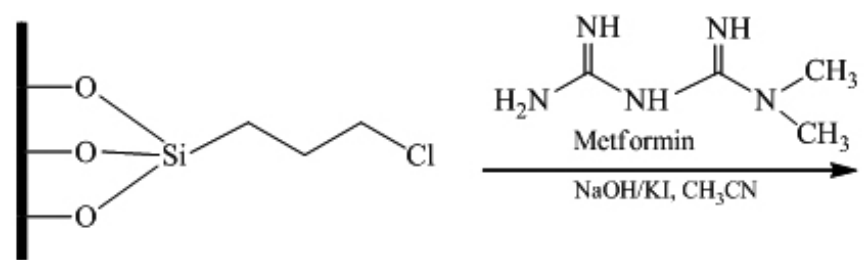

Sillylchloropropyl-functionalized SBA-15

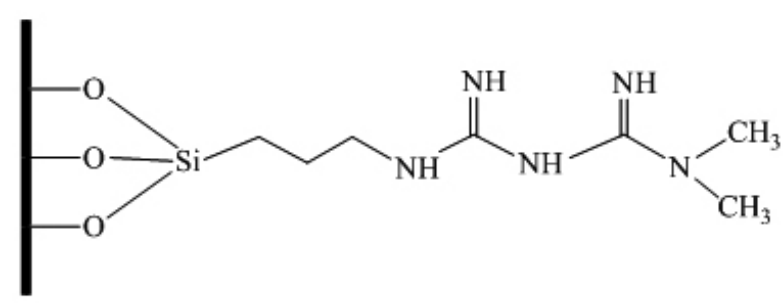

Functionalized Mesoporous SBA-15/Metformin

Scheme 2a. The pathway for the synthesis of functionalized mesoporous SBA-15/Metformin. 


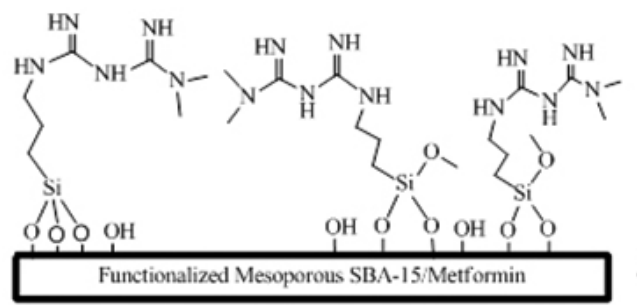

$\mathrm{Pd}(\mathrm{OAc})_{2} /$ Acetone $/ 24 \mathrm{~h}$

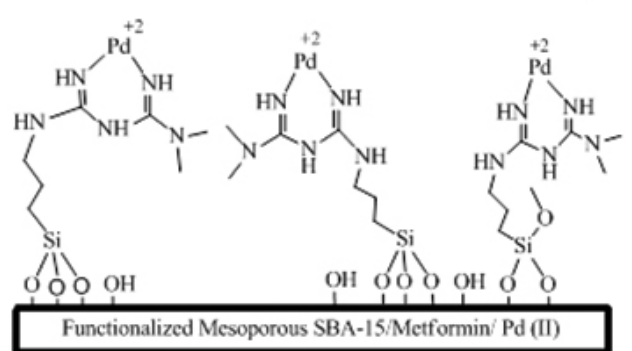

Scheme $2 \mathbf{b}$. The pathway for the synthesis of functionalized mesoporous SBA-15/Metformin/Pd (II).

SBA-15/Metformin was prepared according to the reported method ${ }^{28}$. Then, palladium acetate was added to SBA-15/Metformin in acetone and the mixture was stirred for $24 \mathrm{~h}$ at room temperature to obtain SBA-15/Metformin/ Pd(II). Synthesized catalyst has been characterized by FT-IR, XRD spectra and SEM and TEM images. The SEM micrograph of the catalyst is shown in Fig. 1. This figure shows agglomeration of spherical particles in the range of 50 to $60 \mathrm{~nm}$ (Figure 1).

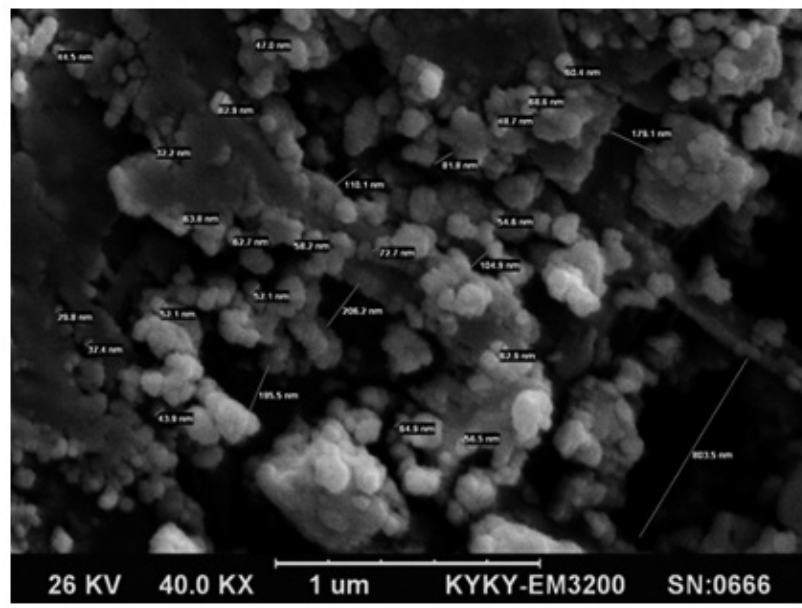

Figure 1. SEM image of modified SBA-15/metformin/palladium catalyst

TEM image of catalyst clearly shows the activated sites of Pd particles trapped in metformin net in the size range of 5-15 nm (Figure 2).

The successful attachment of metformin and subsequent coordination of Pd (II) ions within the mesoporous SBA-15 material can be achieved by employing of FT-IR spectroscopy. Fig. 3 shows the FT-IR spectra obtained for (a) Metformin hydrochloride (Metformin.HCl), (b) Parent SBA-15, (c) Functionalized SBA-15, (d) Functionalized SBA-15/Metformin and (e) Functionalized SBA-15/Metformin/Pd (II).

Curve (a) shows the FT-IR spectrum of Metformin. $\mathrm{HCl}$ and signals appeared at 1568 and $1634 \mathrm{~cm}^{-1}$ are attributed to the presence of $\mathrm{C}=\mathrm{N}$ stretching vibrations ${ }^{29}$. The signals appeared at $3150-3400 \mathrm{~cm}^{-1}$ region can be assigned to the $\mathrm{N}-\mathrm{H}$ stretching of $\mathrm{C}=\mathrm{N}-\mathrm{H}$ group on metformin ${ }^{30}$. The unmodified SBA-15 spectrum in curve (b) shows the typical silica bands associated with the main inorganic backbone, the signals appeared at 1000 and $1200 \mathrm{~cm}^{-1}$ are assigned to asymmetric stretching of Si-O-Si, the peak at $1620 \mathrm{~cm}^{-1}$ is related to the bending vibration of water bonded to the inorganic backbone and signal appeared at
$3430 \mathrm{~cm}^{-1}$ can be assigned to O-H stretching frequency of Si-O-H groups and/ or water in atmosphere and within porous sample. The functionalized SBA-15 spectrum in curve (c) shows the similar bands like as prepared SBA-15. In curves (d) and (e), the broad band at $1050-1250 \mathrm{~cm}^{-1}$ is related to asymmetrical stretching bond of Si-O-Si bridges, being indicative of the existence of a silica material and an apparent signal in $965 \mathrm{~cm}^{-1}$ that is ascribed to stretching bond of $\mathrm{Si}-\mathrm{OH}^{31}$. Moreover, a broad signal in the range of $3150-3413 \mathrm{~cm}^{-1}$ approved the existence of free surface $\mathrm{OH}$ and absorbed water on the surface of catalyst and the peaks in $1465 \mathrm{~cm}^{-1}$ and $1641 \mathrm{~cm}^{-1}$ are attributed to $\mathrm{C}-\mathrm{N}$ and $\mathrm{C}=\mathrm{N}$ stretching bond respectively.

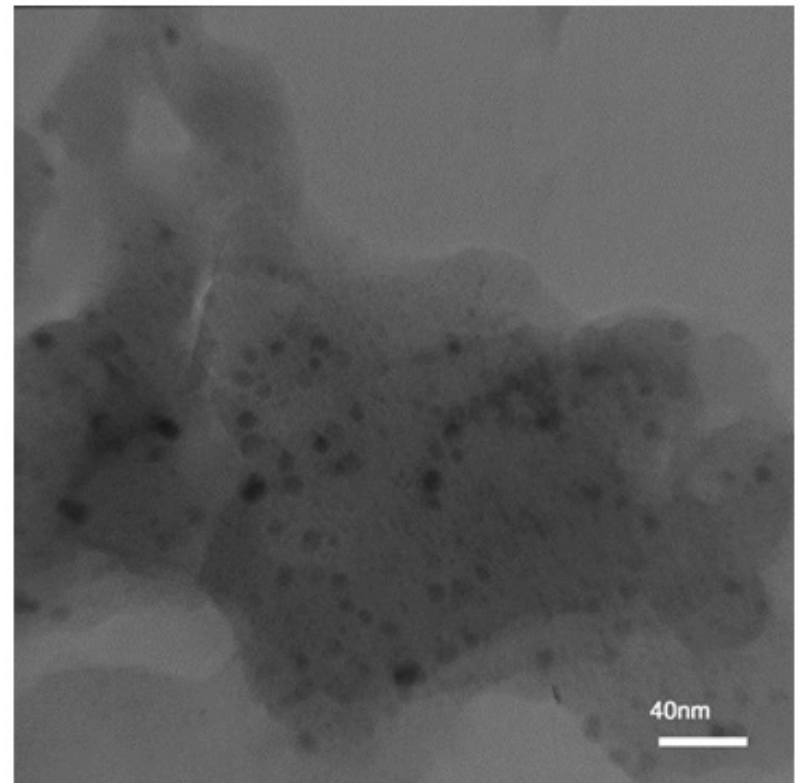

Figure 2. TEM image of modified SBA-15/metformin/palladium catalyst

The significant difference in FT-IR spectra of Metformin. $\mathrm{HCl}$ and SBA15/Metformin (curves (a) and (d)) was the shift of $\mathrm{C}=\mathrm{N}$ stretching frequencies from 1568 and $1634 \mathrm{~cm}^{-1}$ to broad band in $1646 \mathrm{~cm}^{-1}$, due to the removal of $\mathrm{HCl}$ when metformin is attached to the silica surface. On the other hand, the metal-ligand coordination ${ }^{30,32}$ presumably leads to a shift of these two peaks again to lower frequencies $\left(1568\right.$ and $\left.1634 \mathrm{~cm}^{-1}\right)$. This shift can be observed in compare with curves (d) and (e) in Fig. 3. On the whole, the aforementioned observations confirmed the immobilization of Pd(II) ions on the surface of SBA-15/Metformin.

The XRD pattern of catalyst shows no specific signals due to conversion of crystalline form of catalyst to amorphous morphology caused by encaging of $\mathrm{Pd}$ into the surface structure by eliminating of signals which were observed in three distinct diffraction peaks in low $2 \theta$ region before treating with $\mathrm{Pd}(\mathrm{OAc})_{2}$ solution (Fig 4a and 4b).

BET specific surface areas of SBA- 15 and modified SBA- 15 by metformin were measured in 1050 and $445 \mathrm{~m}^{2} / \mathrm{g}$ respectively. This result shows that the surface area of treated sample with metformin is dramatically reduced. The surface area of palladium treated functionalized SBA-15/metformin sample slightly changed and finally reached to $440 \mathrm{~m}^{2} / \mathrm{g}$. It can be concluded that palladium mostly trapped by metformin instead of the void pores of SBA-15.

To assume that prepared catalyst hydrogenates different alkynes with highly selectivity to only (Z)-isomer of corresponding alkenes (scheme 1) and for confirming this theory, more than 10 different alkynes were treated by this catalyst in hydrogenation reaction and unanimously results, approved proposed assumption. Structure of reduced product characterized by FT-IR and ${ }^{1} \mathrm{H}$ NMR, ${ }^{13} \mathrm{CNMR}$ and MS spectra that were clearly in agreement with the corresponding alkenes. The results summarized in Table 1 . 

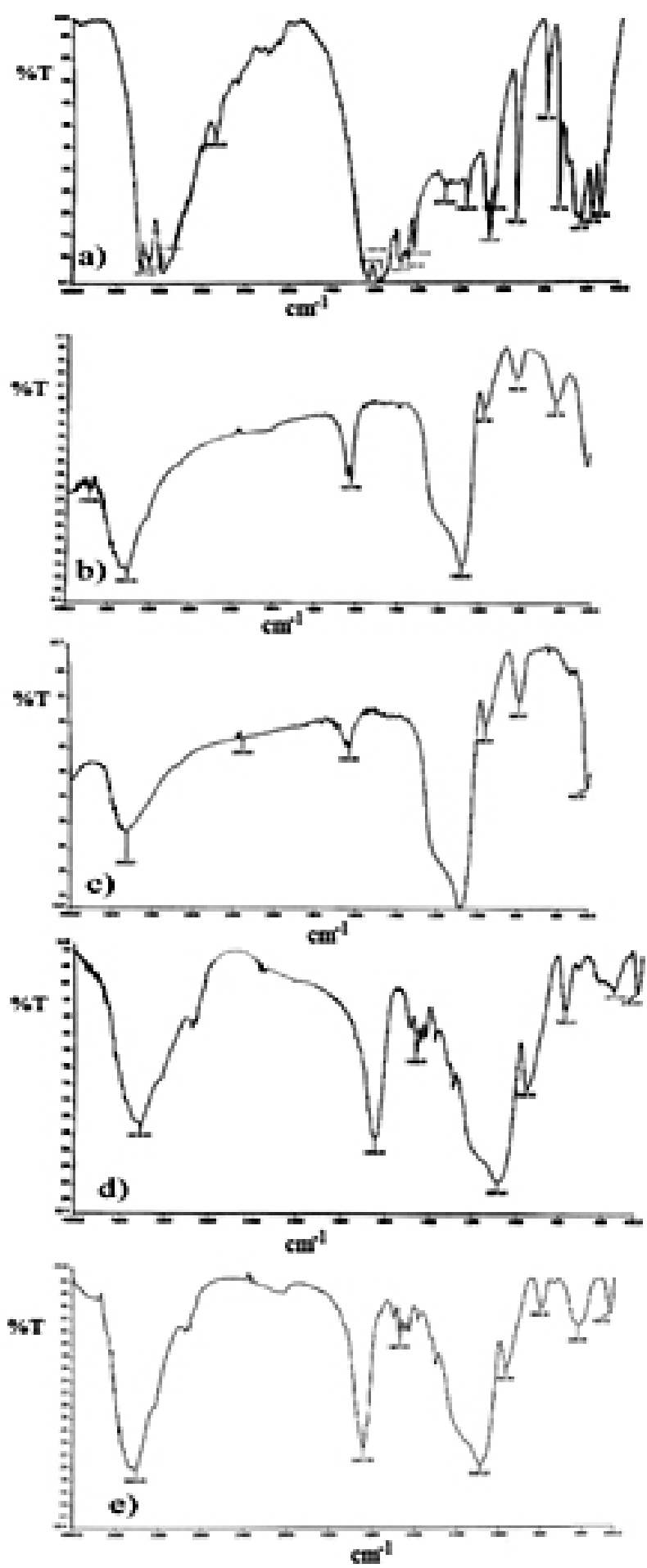

Figure 3. FT-IR spectra for samples of (a) Metformin hydrochloride, (b) Parent SBA-15, (c) Functionalized SBA-15, (d) Functionalized SBA-15/ Metformin and (e) Functionalized SBA-15/Metformin /Pd(II) catalyst.

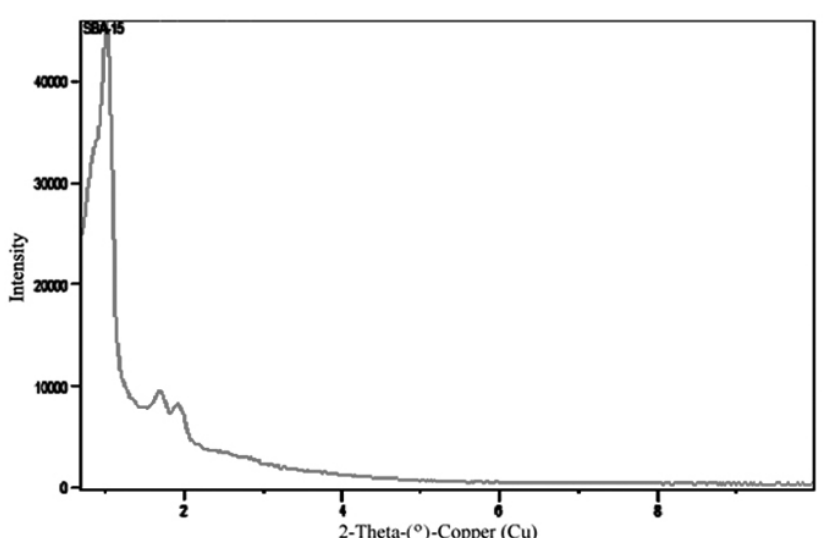

Figure 4a. XRD spectrum of SBA-15

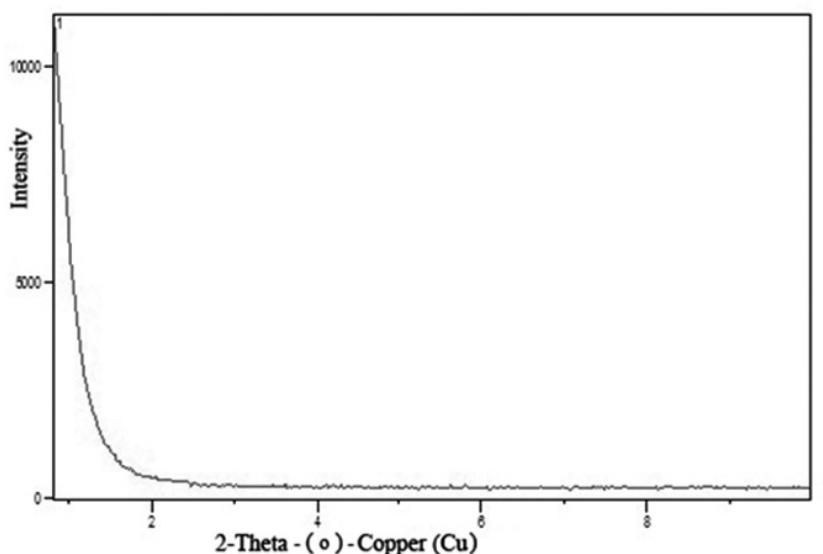

Figure 4b. XRD spectrum of Functionalized SBA-15/metformin /Pd(II) catalyst

Reactions were completed during 4-6 $\mathrm{h}$ and the configuration of resulted products were determined as a cis alkenes. For example, the ${ }^{1} \mathrm{H}$ NMR spectrum of $2 \mathrm{i}$ exhibits one singlet for the same two olefin protons in $6.5 \mathrm{ppm}$ that is in agreement with (Z)-structure for stilbene. Aromatic protons appeared in the region between 7-7.5 ppm with expected pattern for mono substituted benzene. FT-IR spectrum of resulted product clearly approved the conversion of triple bond to Z-isomer of double bond by strong peak appeared in $1600 \mathrm{~cm}^{-1}$ instead of signal for trans isomer that usually shifted to lower frequencies because of its better conjugation system interaction.

\subsection{Catalyst regenerating and recycling}

Leaching of palladium species from the catalyst support is one of the most commonplace issues for deactivation of catalyst in liquid phase reactions ${ }^{33-35}$. To investigte the activity of used catalyst, the functionalized/metformin/Pd catalyst was recovered, regenerated and reused for selective hydrogenation of typical alkyne, for instance diphenylacetylene three times. The results of comparison with fresh and used catalysts in liquid hydrogenation of diphenylacetylene were summarized in Table 2. 
Table 1. The yields for the partial hydrogenation of alkynes using functionalized Si-SBA-15/metformin/ Pd(II) catalyst

\begin{tabular}{|c|c|c|c|c|c|}
\hline Entry & $\mathrm{R}$ & $\mathrm{R}^{\prime}$ & Product & Time (h) & Yield (\%) \\
\hline $2 \mathrm{a}$ & $-\mathrm{Ph}$ & $-\mathrm{H}$ & phenylethylene & 5.0 & 80 \\
\hline $2 \mathrm{~b}$ & $-\mathrm{CH}_{2} \mathrm{OH}$ & $-\mathrm{H}$ & 2-propen-1-ol & 4.5 & 98 \\
\hline $2 \mathrm{c}$ & $-\mathrm{CH}_{2} \mathrm{OH}$ & $-\mathrm{CH}_{3}$ & (Z)-2-buten-1-ol & 5.5 & 95 \\
\hline $2 \mathrm{~d}$ & $-\mathrm{CH}_{2} \mathrm{CH}_{2} \mathrm{OH}$ & $-\mathrm{H}$ & 3-buten-1-ol & 4.5 & 92 \\
\hline $2 \mathrm{e}$ & $-\mathrm{CH}-\mathrm{CH}_{3} \mathrm{OH}$ & $-\mathrm{H}$ & 3-buten-2-ol & 5.0 & 90 \\
\hline $2 \mathrm{f}$ & $-\mathrm{CH}_{2} \mathrm{OH}$ & $-\mathrm{CH}_{2} \mathrm{OH}$ & (Z)-2-buten-1,4-diol & 5.5 & 98 \\
\hline $2 \mathrm{~g}$ & $-\mathrm{H}$ & $-\mathrm{COOH}_{2}$ & propenoic acid & 5.0 & 97 \\
\hline $2 \mathrm{~h}$ & $-\mathrm{COOH}$ & $-\mathrm{COOH}_{2}$ & (Z)-ethylen-dicarboxylic & 5.5 & 94 \\
\hline $2 \mathrm{i}$ & $-\mathrm{Ph}$ & $-\mathrm{Ph}_{2}$ & $(\mathrm{Z})-1,2$ - diphenylethylene & 6.0 & 85 \\
\hline $2 \mathrm{j}$ & $-\mathrm{H}$ & $-\mathrm{CH}_{2} \mathrm{CH}_{2} \mathrm{CH}_{3}$ & 1-pentene & 4.0 & 96 \\
\hline $2 \mathrm{k}$ & $-\mathrm{CH}$ & $-\mathrm{CH}_{2} \mathrm{CH}_{3}$ & (Z)-2-pentene & 4.5 & 91 \\
\hline $2 \mathrm{l}$ & $-\mathrm{H}$ & $-\mathrm{CH}_{2} \mathrm{CH}_{2} \mathrm{CH}_{2} \mathrm{CH}_{3}$ & 1-hexene & 4.5 & 94 \\
\hline $2 \mathrm{~m}$ & $-\mathrm{H}$ & $-\mathrm{CH}_{2}\left(\mathrm{CH}_{2}\right)_{4} \mathrm{CH}_{3}$ & 1-octene & 5.5 & 86 \\
\hline
\end{tabular}

Table 2. Yields for partial hydrogenation of diphenylacetylene to (Z)1,2-diphenylethylene using fresh and used functionalized SBA-15/metformin/ palladium catalysts.

\begin{tabular}{|c|c|c|}
\hline Catalysts & Time (h) & Yield (\%) \\
\hline $\begin{array}{c}\text { Functionalized SBA-15/ } \\
\text { metformin/palladium (fresh) }\end{array}$ & 6 & 85 \\
\hline $\begin{array}{c}\text { Functionalized SBA-15/ } \\
\text { metformin/palladium (used) } \\
\text { (first time) }\end{array}$ & 6 & 83 \\
\hline $\begin{array}{c}\text { Functionalized SBA-15/ } \\
\text { metformin/palladium(used) } \\
\text { (second time) }\end{array}$ & 6.5 & 82 \\
\hline $\begin{array}{c}\text { Functionalized SBA-15/ } \\
\text { metformin/palladium (used) } \\
\text { (third time) }\end{array}$ & 6.5 & 80 \\
\hline
\end{tabular}

\section{CONCLUSION}

In summary, we introduced a novel catalyst for selective partial hydrogenation of alkynes to (Z)-alkenes in good yield. The current method presents a simple and useful synthetic process for partial hydrogenation of alkynes because of the following advantages: (1) easily recycling of catalyst, (2) environmentally benign, (3) highly selectivity and (4) readily to prepare.

\section{REFERENCES}

1. P. T. Witte, M. de Groen, R. M. de Rooij, P. Donkervoort, H. G. Bakermans, J. W. Geus, Stud. Surf. Sci. Catal. 175, 135, (2010)

2. N. Semagina, L. Kiwi-Minsker, Catal. Lett. 127, 334, (2009)

3. A. Molnar, A. Sarkany, M. Varga, J. Mol. Catal. A 173, 185, (2001)

4. M. Crespo-Quesada, F. Cardenas-Lizana, A. L. Dessimoz, L. KiwiMinsker, ACS Catal. 2, 1773, (2012)

5. R. N. Shiju, V. V. Guliants, Appl. Catal. A: Gen. 356, 1, (2009)

6. F. P. D. Silva, L. M. Rossi, Tetrahedron 70, 3314, (2014)

7. S. M. T. Ohkubo, T. I. A. Kume, T. Maegawa, Y. Monguchi, H. Sajiki, J. Molecular Catalysis A: Chemical 307, 77, (2009)
8. Y. L. Y. Motoyama, K. Tsuji, S. H. Yoon, I. Mochida, H. Nagashima, Chem. Cat. Chem. 4, 778, (2012)

9. H. Sajiki, S. Mori, T. Ohkubo, T. Ikawa, A. Kume, T. Maegawa, Y. Monguchi, Chem.-Eur. J. 14, 5109, (2008)

10. C. W. A. Chan, K. Y. Tam, J. Cookson, P. Bishop, S. C. Tsang, Catal. Sci. Technol. 1, 1584, (2011)

11. D. Teschner, J. Borsodi, A. Wootsch, Z. Revay, M. Havecker, A. KnopGericke, S. D. Jackson, R. Schlogl, Science 320, 86, (2008)

12. Z. Re, A. Knop-gericke, R. Schlogl, D. Torres, P. Sautet, J. Phys. Chem. C 114, 2293, (2010)

13. M. Garcia-Mota, B. Bridier, J. Perez-Ramirez, N. Lopez, J. Catal. 273, 92 , (2010)

14. M. Garcia-Mota, J. Gomez-Diaz, G. Novell-Leruth, C. Vargas-Fuentes, L. Bellarosa, B. Bridier, J. Perez-Ramirez, N. Lopez, Theor. Chem. Acc. 128, $663,(2010)$

15. B. Bridier, N. Lopez, J. Perez-Ramirez, Dalton Trans. 39, 8412, (2010)

16. D. Mei, M. Neurock, C. M. Smith, J. Catal. 268, 181, (2009)

17. S. G. Kwon, G. Krylova, A. Sumer, M. M. Schwartz, E. E. Bunel, C. L. Marshall, S. Chattopadhyay, B. Lee, J. Jellinek, E. V. Shevchenko, Nano letters 12, 5382, (2012)

18. A. Mastalir, Z. Kiraly, G. Szollosi, M. Bartok, J. Catal. 194, 146, (2000)

19. A. Mastalir, T. Szabo, Z. Kiraly, I. Dekany, Catal. Commun. 17, 104, (2012)

20. K. H. Lee, B. Lee, K. R. Lee, M. H. Yi, N. H. Hur, Chem. Commun. 48, 4414, (2012)

21. A. Mastalir, Z. Kiraly, J. Catal. 220, 372, (2003)

22. S. D. Jackson, L. A. Shaw, Appl. Catal. A 134, 91, (1996)

23. A. Papp, A. Molnar, A. Mastalir, Appl. Catal. A 289, 256, (2005)

24. N. Marin-Astorga, G. Pecchi, T. J. Pinnavaia, G. Alvez-Manoli, P. Reyes, J. Mol.

Catal. A 247, 145, (2006)

25. R. J. White, R. Luque, V. L. Budarin, J. H. Clark, D. Macquarrie, J. Chem. Soc. Rev. 38, 481, (2009)

26. D. Li, C. Wang, D. Tripkovic, S. Sun, N. M. Markovic, V. R. Stamenkovic, ACS Catal. 2, 1358, (2012)

27. J. Wang, S. Zheng, Y. Shao, J. Liu, Z. Xu, D. Zhu, J. Colloid Interface Sci. 349, 293, (2010)

28. A. Alizadeh, M. M. Khodaei, D. Kordestani, A. H. Fallah, M. Beygzadeh, Microporous Mesoporous Mater. 159, 9, (2012)

29 S. S. Sharma, J. V. Ramani, D. P. Dalwadi, J. J. Bhalodia, N. K. Patel, D. D. Patel, R. K. Patel, E.-J. Chem. 8, 361, (2011) 
30. M. Zhu, L. Lu, P. Yang, X. Jin, Acta Crystallogr. E. 58, 272, (2002)

31. S. Gunasekaran, R. K. Natarajan, V. Renganayaki, S. Natarajan, Indian, J. Pure Appl. Phys. 44, 495, (2006)

32. D. Y. Zhao, J. L. Feng, B. F. Chmelka, G. D. Stucky, J. Am. Chem. Soc. 120, 6024, (1998)

33. K. Kohler, R. G. Heidenreich, J. G. E. Krauter, J. Pietsch, Chem. Eur. J. 8 , $622,(2002)$
34. N. T. S. Phan, M. Van Der Sluys, C. W. Jones, Adv. Synth. Catal. 348 , 609, (2006)

35. D. Astruc, Inorg. Chem. 46, 1884, (2007)

\section{ACKNOWLEDGEMENTS}

We are grateful to Islamic Azad University, East Tehran Branch for financial support. 